\title{
Helminths of mustelids (Mustelidae) in Lithuania
}

\section{Dovilè Nugaraitè,}

Vytautas Mažeika*,

\section{Algimantas Paulauskas}

Faculty of Natural Sciences,

Vytautas Magnus University,

Vileikos str. 8,

LT-44404 Kaunas, Lithuania
This study provides new faunistic data for helminths of mustelids in Lithuania. Twenty-five mustelids were examined for helminths: 2 pine martens (Martes martes), 4 stone martens (Martes foina), 9 American minks (Neovison vison) and 10 European polecats (Mustela putorius). Nine taxa of the parasitic worms were found: trematodes Isthmiophora melis (Schrank, 1788) and Strigea strigis (Schrank, 1788) mesocercaria, cestodes Mesocestoides lineatus Goeze, 1782 and Cestoda g. sp. and nematodes Eucoleus aerophilus (Creplin, 1839), Aonchotheca putorii (Rudolphi, 1819), Crenosoma schachmatovae Kontrimavičius, 1969, Molineus patens (Rudolphi, 1845) and Nematoda g. sp. The biggest infection parameters were detected for flukes Isthmiophora melis and Strigea strigis mesocercaria in American mink and European polecat. In most cases the distribution of helminths in populations of mustelids was aggregated $\left(s^{2} / A>1\right)$.

Key words: mustelids, helminths, Lithuania

\section{INTRODUCTION}

In Lithuania pine marten (Martes martes), stone marten (Martes foina), stoat (Mustela erminea), least weasel (Mustela nivalis), European polecat (Mustela putorius), American mink (Neovison vison), Eurasian badger (Meles meles) and European otter (Lutra lutra) are found. European mink (Mustela lutreola) is an extinct species, not found in Lithuania for some decades (Prūsaitè et al., 1988). Helminths of mustelids have been investigated in Lithuania about 40-50 years ago. In 1959, Maldžiūnaitè investigated 6 Eurasian badgers, 4 pine martens and 2 European polecats. Eleven species of helminths were recorded during 1957-1961 and 1971-1973 investigation of 7 Eurasian badgers, 3 pine martens and 2 European polecats (Kazlauskas, Prūsaite, 1976). In each the flukes of species Isthmiophora

\footnotetext{
* Corresponding author. E-mail: v.mazeika@gmf.vdu.lt
}

melis (recorded under name Euparyphium melis) were found. Both pine marten and Eurasian badger were infected by nematodes Aonchotheca putorii (recorded under name Capillaria putorii) and Filaroides martis. Only Eurasian badger was parasitized by cestode Mesocestoides lineatus and nematodes Trichinella spiralis and Uncinaria stenocephala. Infection of some wild and domestic animals with the nematode of the genus Trichinella was investigated by Senutaite and Grikienienè (2001). From mustelids the highest prevalence (62.5\%) with encapsulated Trichinella larvae was established in pine marten.

\section{MATERIALS AND METHODS}

The material for helminthological study was collected over a period extending from 2011 to 2014, in different places of Lithuania (Fig. 1). Mammals were hunted by hunters or killed in car accidents. All carcasses were stored at $-20{ }^{\circ} \mathrm{C}$ 


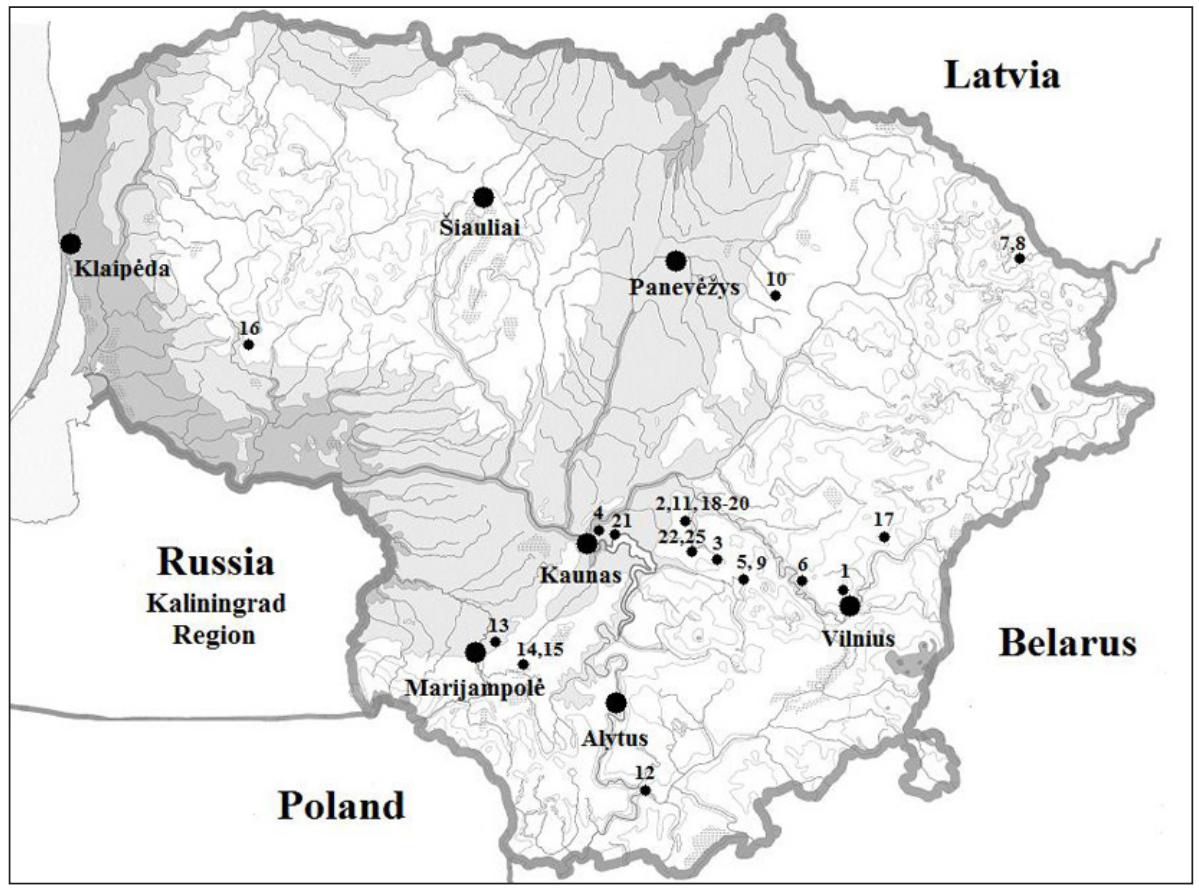

Fig. 1. Mustelids collection sites in Lithuania. 1-2 - pine marten, 3-6 - stone marten, 7-15 - American mink, 16-25 - European polecat

until examination. Two pine martens (Martes martes Linnaeus, 1758), 4 stone martens (Martes foina (Erxleben, 1777)), 9 American minks (Neovison vison (Schreber, 1777)) and $10 \mathrm{Eu}-$ ropean polecats (Mustela putorius (Linnaeus, 1758)) were investigated by a total helminthological examination of individual organs (Ivashkin et al., 1971). Parasites were collected from entire gastrointestinal tract, lungs, heart, liver, kidney, gall bladder and urinary bladder. All organs were divided into anatomical parts and dissected separately. Each fragment was cut longitudinally and examined for parasites. Parasites were collected and stored in 70\% ethanol.

Nematodes were studied after mounting in glycerin. Before the study trematodes and cestodes were stained in carmine, dehydrated and mounted in Canada balsam, afterwards measured and photographed (Fig. 2).

Helminthological terms - mean abundance (A) and prevalence (P\%) were used according to the recommendations of Bush et al. (1997). 95\% confidence intervals for prevalence were calculated as described by Rojtman and Lobanov
(1985). To estimate the parasite aggregation we used the simplest and most commonly used aggregation index: the ratio of the variance to the mean abundance $\left(s^{2} / A\right)$ (Poulin, 1998). Statistical significance of differences from random distribution of helminths $\left(s^{2} / A=1\right)$ was assessed using Student's t-test (Kershaw, 1978).

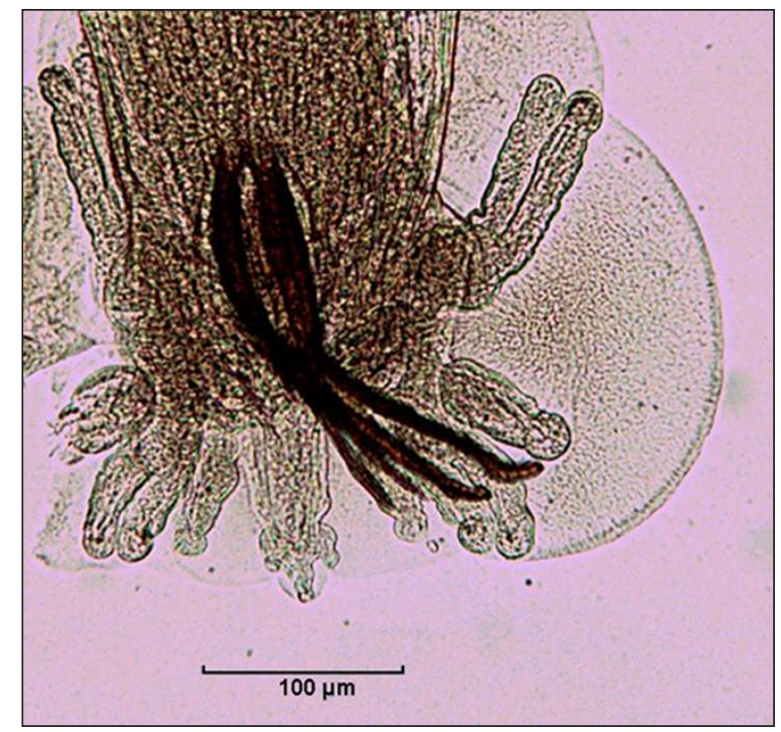

Fig. 2. C. schachmatovae copulatory bursa 
The identification was based on the monograph of Kontrimavičius (1969), the key of Kozlov (1997), Sidorovich (1997), Kostadinova and Gibson (2002) and Vieira et al. (2012).

\section{RESULTS}

Helminthological investigation of 25 mustelids has showed that $92 \%$ animals were infected with helminths. In total, 9 taxa of the parasitic worms were found (two species of them are not identified) relating to the following systematic groups: phylum Platyhelminthes class Trematoda - 2 and Cestoda - 2 and phylum Nematoda -5 . The parameters of mustelids infection with helminths are presented in Table 1.

Stone marten ( $M$. foina) and American mink (N. vison) harbored 6 taxa of helminths. Stone marten was parasitized by Eucoleus aerophilus (Creplin, 1839), Aonchotheca putorii (Rudolphi, 1819), Crenosoma schachmatovae Kontrimavičius, 1969 (Fig. 2), Nematoda g. sp., Mesocestoides lineatus Goeze, 1782 and Cestoda g. sp.

The nematodes E. aerophilus, A. putorii and C. schachmatovae also parasitized in the introduced American mink. Without these species Molineus patens (Rudolphi, 1845), flukes Isthmiophora melis (Schrank, 1788) and Strigea strigis (Schrank, 1788) mesocercaria were found in American mink. The most common helminths species of the introduced mustelid were $I$. melis $(\mathrm{A}=19.4)$ and S. strigis mesocercaria $(\mathrm{A}=5.1)$. Furthermore, six of nine hosts were infected with flukes I. melis. The minimum number of $I$. melis individuals per infected hosts was 2, and the maximum - 76 . The largest number of isolated S. strigis mesocercaria was 28 , and the minimum was 2 per infected hosts.

Only two species of parasites were found in pine marten - A. putorii and M. patens. $M$. patens were found in one pine marten and only two worms, thus mean abundance is 1.0. A. putorii was found in one pine marten too, but its abundance was higher -36.5 .

During helminthological research of 10 European polecats (M. putorius), 5 helminths species were revealed: A. putorii, C. schachmatovae, S. strigis mesocercaria, M. patens and I. melis. The largest number of isolated helminths belonged to the species I. melis (1514) which was found in 9 of 10 investigated European polecats $(\mathrm{P}=90 \%)$. It also had the largest mean abundance $(A=391.3)$. Second species with high parameters of infection was $S$. strigis mesocercaria $(\mathrm{A}=11.6, \mathrm{P}=50 \%)$.

The distribution of three nematodes species was aggregated in stone marten (E. aerophilus $\left(s^{2} / A=4.8\right)$, A. putorii $\left(s^{2} / A=4.0\right)$, C. schachmatovae $\left.\left(s^{2} / A=2.0\right)\right)$. Aggregation indices for Nematoda g. sp., M. lineatus and Cestoda g. sp. were 1. Data of helminths aggregation index in mustelids are presented in Table 2. The distribution of all parasite species was highly aggregated in European polecat. The highest value of the aggregation index was found for $I$. melis $\left(s^{2} / A=635.5\right)$. All helminths species were aggregated $\left(s^{2} / A>1\right)$ in American mink and pine marten except that of M. patens in American mink and European polecat - the variance / mean ratio of parasite numbers per host is not significantly greater than one $(t<t c r)$.

\section{DISCUSSION}

According to our research the mustelids were infected with 9 species of the parasitic worms. In stone marten 6 helminths taxa were found. Similar results are observed in north-eastern Italy, 8 stone martens were infected with 5 species of helminths (Di Cerbo et al., 2008). Furthermore, one stone marten helminthological investigation in southern Italy revealed 10 helminths species (Ribas et al., 2004). Parasites species richness was low in Poland (4 species) (Kornaś et al., 2013).

Two species of flukes were found in N. vison and M. putorius: Isthmiophora melis and Strigea strigis mesocercaria. I. melis belongs to the family Echinostomatidae and had one of the most complicated and richest history (Kostadinova, Gibson, 2002). This species parasitizes in small intestine of order Carnivora in Europe, Asia and North America (Kostadinova, Gibson, 


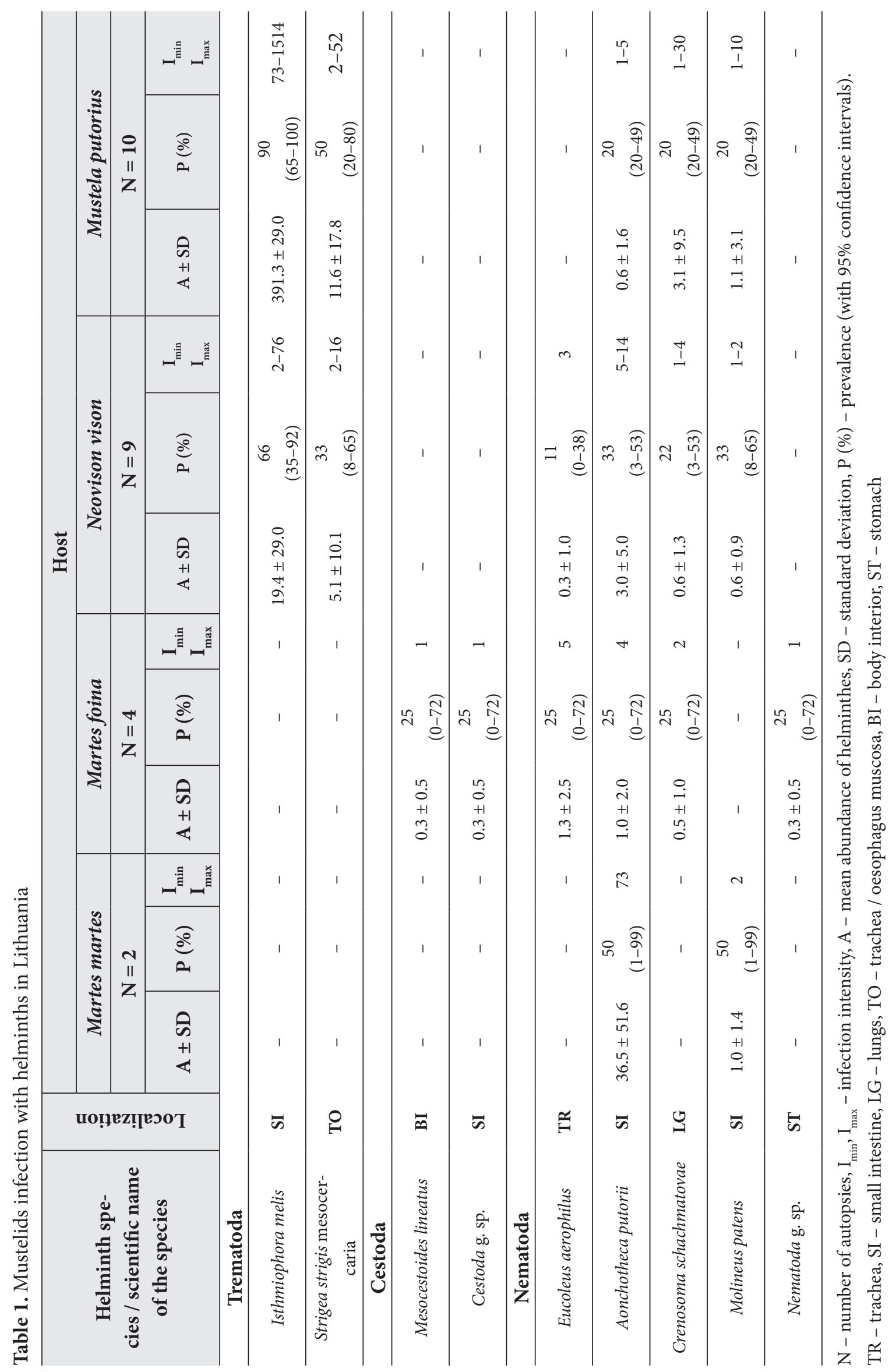


Table 2. Helminths aggregation index in mustelids

\begin{tabular}{|c|c|c|c|c|}
\hline \multirow{2}{*}{$\begin{array}{l}\text { Helminths species / scientific } \\
\text { name of the species }\end{array}$} & \multicolumn{4}{|c|}{ Aggregation index } \\
\hline & Martes martes & Martes foina & Neovison vison & Mustela putorius \\
\hline \multicolumn{5}{|l|}{ Trematoda } \\
\hline Isthmiophora melis & - & - & $43.4^{*}$ & $635.5^{\star}$ \\
\hline Strigea strigis mesocercaria & - & - & $19.7^{\star}$ & $24.4^{*}$ \\
\hline \multicolumn{5}{|l|}{ Cestoda } \\
\hline Mesocestoides lineatus & - & 1.0 & - & - \\
\hline Cestoda g. sp. & - & 1.0 & - & - \\
\hline \multicolumn{5}{|l|}{ Nematoda } \\
\hline Eucoleus aerophilus & & $4.8^{*}$ & $3.0^{*}$ & - \\
\hline Aonchotheca putorii & $72.9^{*}$ & $4.0^{*}$ & $8.7^{\star}$ & $3.3^{*}$ \\
\hline Crenosoma schachmatovae & - & $2.0^{*}$ & $3.6^{*}$ & $28.7^{\star}$ \\
\hline Molineus patens & 4.0 & - & 1.8 & $9.1^{\star}$ \\
\hline Nematoda g.sp. & - & 1.0 & - & - \\
\hline
\end{tabular}

2002; Radev et al., 2009). It is important in veterinary and medicine as it can parasitize more than thirty species of vertebrates including humans (Radev et al., 2009). I. melis had the highest mean abundance and prevalence of all helminths (in N. vison $\mathrm{A}=19.4, \mathrm{P}=66 \%$ and in $M$. putorius $\mathrm{A}=391.3, \mathrm{P}=90 \%)$. It also was the most prevalent species in Belorussian Polesie $(P=47.5)$, whilst the number of flukes per host varied from 1 to 177 (Shimalov, Shimalov, 2001). High infection parameters of flukes in mustelids can be explained by the adaptation of parasite and host to the same living environment and host diet. European polecat and especially American mink are usually found at the rivers and lakes (Bevanger, Henriksen, 1995). First intermediate host of I. melis is aquatic mollusc of family Lymnaeidae, second intermediate host (in which metacercaria are found) - tadpoles and fishes (Kostadinova, Gibson, 2002; Hildebrand et al., 2013), so this factor can increase the likelihood of infection of mustelids by the flukes.

Second species with high parameters of infection was S. strigis mesocercaria in American mink and European polecat. Flukes S. strigis have two intermediate hosts and paratenic hosts, what makes life cycle complex (Shul'ts, Gvozdev, 1972).
M. lineatus was found in one stone marten. Tapeworm belongs to order Cyclophyllidea. It requires a three-host life cycle to complete its development (Shin-Hyeong et al., 2013). The first intermediate host is coprophagic arthropods, such as ants (Padgett, Boyce, 2005). The second intermediate host is small mammals: birds, rodents, reptiles and amphibians (Bonfanti et al., 2004). The adult tapeworm is localized in the small intestine of carnivorous mammals: cats, foxes, skunks, mustelids, coyotes and birds (Ribas et al., 2004). Distribution of species includes North and South America, Europe, Middle East, Africa, India, Southeast Asia, Japan and China (Bowman et al., 2002). Rear cases of human infection with $M$. lineatus are registered (Fuentes et al., 2003).

E. aerophilus (previously known as Capillaria aerophila) had a low mean abundance in stone marten $(\mathrm{A}=1.3)$ and American mink $(\mathrm{A}=0.3)$. According to Torres et al. (2008), high abundance of E. aerophilus was detected in European mink (M. lutreola) $(\mathrm{A}=89.38)$ and in European polecat (M. putorius) $(\mathrm{A}=17.67)$ in south-western France. E. aerophilus affects trachea and main bronchi (Nithikathkul et al., 2011) of canids, felids and some carnivorous animals (Bowman et al., 2002) and in rear cases infects humans (Laloševic' et al., 2008). The 
life cycle of E. aerophilus includes direct transmission, and indirect transmission through earthworm's facultative intermediate host. Females produce non-larvated eggs which reach the environment via the faeces. The eggs mature in the environment, but may also mature within earthworms. Definitive hosts become infected by ingesting the larvated eggs or, more rarely, the invertebrates (Anderson, 2000; Traversa et al., 2011).

A. putorii is a common parasite of wild mammals such as bobcats, raccoons, minks, and other mammals (Campbell, 1991) and is found in the stomach and small intestine of mustelids (Anderson, 1992). It has been reported in North America, Europe (Campbell, 1991) and New Zealand (Collins, Charleston, 1972). A. putorii has direct (by ingestion of larvated eggs) and indirect (by ingestion of oligochaetes containing larvae) life cycle (Skarbilovich, 1945).

C. schachmatovae is found in lungs of mustelids (Kontrimavičius, 1969). According to Kontrimavičius (1969), the species was detected in stoat (M. erminea) in Karelia. Other species of the genus Crenosoma found in the mustelids are as follows: C. schulzi (Górski et al., 2006), C. taiga (Shimalov, Shimalov, 2002), C. melesi (Jancev, Genov, 1988; Torres et al., 1996-1997; Torres et al., 2001; Torres et al., 2008), C. petrowi (Ribas et al., 2004; Torres et al., 2006). Species of family Crenosomatidae are parasitized in the bronchi, frontal sinuses and veins of insectivorous and carnivorous mammals (Vieira et al., 2012). Species of genus Crenosoma are found in Europe, Asia and North America (Torres et al., 2001, 2008). Most information is available about life cycle of C. vulpis, which has an indirect life cycle (Anderson, 1992). Intermediate hosts include terrestrial snails and slugs (Stockdale, Hulland, 1970), definitive hosts include wild and domestic canids and various other carnivores (Traversa et al., 2010).

Nematode $M$. patens is one of the most prevalent species in mustelids. This assertion is supported by the studies in South Florida
(Foster et al., 2007) and Italy (Ribas et al., 2004). Furthermore, M. patens was the most dominated species of weasels (Mustela nivalis) in Spain (Torres et al., 1996-1997). However, in our study infection parameters of $M$. $p a$ tens were low. $M$. patens parasitizes in raccoon dogs, foxes and various mustelids and is found in many countries of Palaearctic and Nearctic (Popiołek et al., 2009). The life cycle of species of genus Molineus is unknown, but nematodes of family Trichostrongylidae have a direct life cycle (Shul'ts, Gvozdev, 1972).

Mustelids are definitive hosts for identified to species level helminths except $S$. strigis, in this case they are paratenic hosts. Helminths E. aerophilus, A. putorii and M. patens have a direct life cycle. Nematode C. schachmatovae, trematodes and cestodes have intermediate hosts.

In many cases the distribution of the helminths in populations of mustelids was aggregated $\left(s^{2} / A>1\right)$. These results strongly depend on direct reproduction of parasites (Poulin, 1998), host age, sex, geographical distribution, genetic variation of species (Wakelin, 1986). According to Haukisalmi (1986), tapeworms have a much lower aggregation index conversely as other parasites. Moreover, one of the features of tapeworms is their size. This factor can increase strongly competition within.

\section{CONCLUSIONS}

Nine taxa of helminths parasitized in 25 mustelids: flukes Isthmiophora melis and Strigea strigis mesocercaria, tapeworms: Mesocestoides lineatus and Cestoda g. sp. and nematodes: $\mathrm{Eu}$ coleus aerophilus, Aonchotheca putorii, Crenosoma schachmatovae, Molineus patens and Nematoda g. sp., I. melis and S. strigis mesocercaria had the highest mean abundance and prevalence of all helminths. Some species have a zoonotic potential, e. g. E. aerophilus, M. lineatus and I. melis can infect humans.

In many cases the distribution of helminths in populations of mustelids was aggregated $\left(s^{2} / A>1\right)$. 


\section{ACKNOWLEDGEMENTS}

The study was partially supported by Research Council of Lithuania (Grant No. LEK-14/2012).

Received 06 June 2014

Accepted 28 August 2014

\section{References}

1. Anderson RC. Nematode parasites of vertebrates; their development and transmission. CABI, New York 1992; 672.

2. Anderson RC. Nematode Parasites of Vertebrates. Their Development and Transmission. 2nd ed. Guilford, UK: Cabi Publishing 2000; 672.

3. Bevanger K, Henriksen G. The distributional history and present status of the American mink (Mustela vison Schreber) in Norway. Ann Zool Fennici 1995; 32: 11-4.

4. Bonfanti U, Bertazzolo W, Pagliaro L, Demarco B, Venco L, Casiraghi M, Bandi C. Clinical, cytological and molecular evidence of Mesocestoides sp. infection in a dog from Italy. J Vet Med A Physiol Pathol Clin Med 2004; 51(910): $435-8$.

5. Bowman DD, Hendrix CM, Lindsay DS, Barr SC. Fenine clinical parasitology. Iowa State University Press, United States 2002; 469.

6. Bush AO, Lafferty KD, Lotz JM, Shostak AW. Parasitology meets ecology on its own terms: Margolis et al. revisited. J Parasitol 1997; 83(4): 575-83.

7. Campbell BG. Trichuris and other Trichinelloid nematodes of dogs and cats in the United States. Compend Contin Educ Pract Vet 1991; 13: 769-78.

8. Collins GH, Charleston WAG. Letter: Ollulanus tricuspis and Capillaria putorii in New Zealand cats. (Correspondence). N Z Vet J 1972; 20(5): 82.

9. Di Cerbo AR, Manfredi MT, Bregoli M, Ferro Milone N, Cova M. Wild carnivores as source of zoonotic helminths in north-eastern Italy. Helminthologia 2008; 45(1): 13-19.

10. Foster GW, Cunningham MW, Kinsella JM, Owen M. Parasitic Helminths of Free-Ranging Mink (Neovison vison mink) from Southern Florida. J Parasitol 2007; 93(4): 945-6.

11. Fuentes MV, Galán-Puchades MT, Malone JB. A new case report of human Mesocestoides infection in the United States. Am J Trop Med Hyg 2003; 68: 566-7.

12. Górski P, Zalewski A, Łakomy M. Parasites of carnivorous mammals in Białowieża Primeval Forest. Wiad Parazytol 2006; 52(1): 49-53.

13. Haukisalmi V. Frequency distributions of helminths in microtine rodents in Finnish Lapland. Ann Zool Fennici 1986; 23: 141-50.

14. Hildebrand J, Adamczyk M, Zaleśny G, Laskowski Z. Variability within species Isthmiophora melis (Digenea, Echinostomatinae) molecular analysis vs. Morphological analysis. Ann Parasitol 2013; 59: 17.

15. Ivashkin VM, Kontrimavičius VN, Nazarova NS. Methods of collaction and study of terrestrian mammal helminthes. Nauka, Moscow 1971; 124. (in Russian).

16. Jancev J, Genov T. On the morphology and taxonomy of species from the genus Crenosoma Molin, 1861 (Nematoda: Crenosomatidae) in Bulgaria. Helminthology 1988; 25: 45-63.

17. Kazlauskas J, Prūsaite J. Helminths of carnivores in Lithuania. Acta Parasitol Lithuan 1976; 12: 33-40. (in Russian).

18. Kershaw KA. 1978. Ilościowa i dynamiczna ekologija roślin. PWN, Warszawa; 382.

19. Kontrimavičius VN. 1969. Helminths of mustelids and trends in their evolution. Nauka, Moscow 1969; 432. (in Russian).

20. Kornaś S, Wierzbowska IA, Górski P, Okarma $\mathrm{H}$. Occurrence of internal parasites in stone martens (Martes foina) from Cracow and suburbs. Ann Parasitol 2013; 59(4): 203-5.

21. Kostadinova A, Gibson DI. Isthmiophora Lühe, 1909 and Euparyphium Dietz, 1909 (Digenea: 
Echinostomatidae) re-defined, with comments on their nominal species. Syst Parasit 2002; 52: 205-17.

22. Kozlov DP. Key to Helminths of Carnivorous Mammals of the USSR. Nauka, Moscow 1977; 231. (in Russian).

23. Laloševic' D, Laloševic' V, Klem I, StanojevJovanovic' D, Pozio E. Pulmonary Capillariasis Miming Bronchial Carcinoma. Am J Trop Med Hyg 2008; 78(1): 14-6.

24. Maldžiūnaitè S. Some data on the parasites of mustelids in the Lithuanian S.S.R. Acta Parasitol Lithuan 1959; 2: 57-9. (in Russian).

25. Nithikathkul C, Saichua P, Royal L, Cross JH. Capillariosis, in Oxford Textbook of Zoonoses, 2nd Edition, Biology, Clinical Practice, and Public Health Control. Oxford University Press, Oxford 2011; 727-37.

26. Padgett KA, Boyce WM. Ants as first intermediate hosts of Mesocestoides on San Miguel Island, USA. J Helminthol 2005; 79: 67-73.

27. Popiołek M, Jarnecki H, Łuczyński T. The first record of Molineus patens (Dujardin, 1845) (Nematoda, Molineidae) in the ermine (Mustela erminea L.) in Poland. Wiad Parazyt 2009; 55(4): 433-5.

28. Poulin R. Evolutionary ecology of parasites from individuals to communities. Springer, London 1998; 212.

29. Prūsaitė J, Mažeikytė R, Pauža D, Paužienè N, Juškaitis R, Mickus A, Grušas A, Skeiveris $\mathrm{R}$, Bluzma P, Bielova O, Baranauskas K, Mačionis A, Balčiauskas L, Janulaitis Z. Fauna of Lithuania. Mokslas, Vilnius 1988; 294.

30. Radev V, Kanev I, Khrusanov D, Fried B. Reexamination of the life cycle of Isthmiophora melis (Trematoda: Echinostomatidae) on material from southeast Europe. Parazitologiia 2009; 43(6): 445-53.

31. Ribas A, Milazzo C, Foronda P, Casanova JC. New data on helminths of Stone marten, Martes foina (Carnivora, Mustelidae), in Italy. Helmithologia 2004; 41(1): 59-61.

32. Rojtman VA, Lobanov AL. Method of estima- tion of parasite hemipopulation abundance in host population. In: Research on Morphology, Taxonomy and Biology of Bird Helminths. Proceedings of Helminthology Laboratory. Vol. XXXIII. Nauka, Moscow 1985; 102-123. (in Russian).

33. Senutaitè J, Grikienienè J. Prevalence of Trichinella in muscles of some domestic and wild mammals in Lithuania and their impact on the organism. Acta Zool Lithuan 2001; 11: 395-404.

34. Shimalov VV, Shimalov VT. Helminth fauna of the American mink (Mustela vision Schreber, 1777) from Belorussian Polesie. Parasitol Res 2001; 87(10): 886-7.

35. Shimalov VV, Shimalov VT. Helminth fauna of the European polecat (Mustela putorius Linnaeus, 1758) in Belorussian Polesie. Parasitol Res 2002; 88: 259-60.

36. Shin-Hyeong C, Tong-Soo K, Yoon K, Byoung-Kuk N, Woon-Mok S. Tetrathyridia of Mesocestoides lineatus in Chinese Snakes and Their Adults Recovered from Experimental Animals. Korean J Parasitol 2013; 51: 531-6.

37. Shul'ts RS, Gvozdev EV. Basics of general helminthology. Vol. 2 Nauka, Moscow 1972: 515. (in Russian).

38. Sidorovich VE. (ed.) Mustelids in Belarus. Evolutionary Ecology, Demography and Interspecific Relationships. Zolotoy uley, Minsk 1997; 289. (in Russian).

39. Skarbilovich TS. Determination of two different types of development cycles in Capillaria putorii (Rud., 1819). Dokl Akad Nauk 1945; 50: 553-4. (in Russian).

40. Stockdale PHG, Hulland TJ. The pathogenesis, route of migration, and development of Crenosoma vulpis in a dog. Pathol Vet 1970; 7: 28-42.

41. Torres J, Miquel J, Feliu C, Motje M, Casanova JC. Helminthological investigation of Mustela nivalis Linnaeus, 1766 in Spain - a mustelid broadly spread all over Western Europe and hardly studied from a parasitic viewpoint. Parasitol Hung 1996-1997; 29-30: 55-66. 
42. Torres J, Miquel J, Motje M. Helminth parasites of the Eurasian badger (Meles meles L.) in Spain: biogeographic approach. Parasitol Res 2001; 87(4): 259-63.

43. Torres J, Miquel J, Manias S, Asensio V, Eira C, Palazon S. Cranial helminths of Mustela vison Schreber, 1777 in Spain. Vet Parasitol 2006; 137(3-4): 379-85.

44. Torres J, Miquel J, Fournier P, FournierChambrillon C, Liberge M, Fons R, Feliu C. Helminth communities of the autochthonous mustelids Mustela lutreola and M. putorius and the introduced Mustela vison in south-western France. J Helminthol 2008; 82(4): 349-55.

45. Traversa D, di Cesare A, Conboy G. Canine and feline cardiopulmonary parasitic nematodes in Europe: emerging and underestimated. Parasit Vectors 2010; 3: 62.

46. Traversa D, Di Cesare A, Lia RP, Castagna G, Meloni S, Heine J, Strube K, Milillo P, Otranto D, Meckes O, Schaper R. New Insights into Morphological and Biological Features of Capillaria aerophila (Trichocephalida, Trichuridae). Parasitol Res 2011; 109: 97-104.

47. Vieira FM, Muniz-Pereira LC, Lima SS, Moraes Neto AHA, Gonçalves PR, Luque JL. Crenosoma brasiliense sp. n. (Nematoda: Metastrongyloidea) parasitic in lesser grison, Galictis cuja (Molina, 1782) (Carnivora, Mustelidae) from Brazil, with a key to species of Crenosoma Molin, 1861. Folia Parasitol (Praha) 2012; 59(3): 187-94.

48. Wakelin D. The role of the immune response in helminth population regulation. I J Parasitol 1986; 17(2): 549-57.

\section{Dovilè Nugaraitė, Vytautas Mažeika, Algiman- tas Paulauskas}

\section{KIAUNINIŲ (MUSTELIDAE) GYVŪNŲ HEL- MINTAI}

\section{Santrauka}

Tyrimas suteikia naujų duomenų apie kiauninių gyvūnų helmintų fauną Lietuvoje. Helmintologinio skrodimo metodu ištirti 25 kiauninių šeimos atstovai: 2 miškinès kiaunès (Martes martes), 4 akmeninès kiaunès (Martes foina), 9 kanadinès audinès (Neovison vison) ir 10 juodųjų šeškų (Mustela putorius). Rasti 9 taksonų helmintai: siurbikès Isthmiophora melis (Schrank, 1788) ir Strigea strigis (Schrank, 1788) mezocerkarijos; kaspinuočiai: Mesocestoides lineatus (Goeze, 1782), Cestoda g. sp.; nematodai: Eucoleus aerophilus (Creplin, 1839), Aonchotheca putorii (Rudolphi, 1819), Crenosoma schachmatovae (Kontrimavičius, 1969), Molineus patens (Rudolphi, 1845), Nematoda g. sp. Pagal užsikrètimo rodiklius dominuojančios parazitų rūšys - siurbikès Isthmiophora melis ir Strigea strigis mezocerkarijos, rastos kanadineje audineje ir juodajame šeške. Daugeliu atvejų helmintų pasiskirstymas kiauninių gyvūnų populiacijoje yra agreguotas $\left(s^{2} / A>1\right)$.

Raktažodžiai: kiauniniai gyvūnai, helmintai, Lietuva 